\title{
Sustainable Methods and Techniques in Old and New
} Public Constructions

\author{
Mauricio Noya ${ }^{1}$, Ana Lucia Torres Seroa da Motta ${ }^{1}$ and Wagner Abreu ${ }^{2}$ \\ 1. Department of Civil Engineering, Universidade Federal Fluminense (UFF), Niterói 24210-240, Brazil \\ 2. Brazilian Institute of Geography and Statistics, Rio de Janeiro 20021-120, Brazil
}

\begin{abstract}
This article is about the methods and techniques used in the building "retrofit" in modernist style designed by the architect Affonso Eduardo Reidy in the fifties, and also about the project of the new Rio de Janeiro MIS (Museum of Image and Sound), under construction, by The North-American office Diller Scofidio + Renfro, both located in the city of Rio de Janeiro. These constructions present a wide view of the concept of sustainability, not commonly used in public buildings in Brazil. In the building designed by Reidy, which belongs to the State of Rio de Janeiro, the regeneration to host the new headquarters of the State Department of Taxation and Finance respected its original characteristics and used smart and sustainable design techniques, as well as recyclable materials. On the other hand, the project of the new museum at Copacabana Beach was entirely planned on sustainable bases and it includes the application of building techniques concerning that purpose. This article presents a study of these two cases and evaluates the techniques and materials used in one another. Observing the principles of sustainability in construction is a pioneering initiative of the State Government. This article aims at making the scientific community aware of the needs of immediate adoption of sustainability techniques in Civil Engineering, not only in the construction of new buildings, but also in the regeneration of the existing ones, as well as the need of imperious adoption of sustainable techniques when it comes to maintainability.
\end{abstract}

Key words: Sustainability, building techniques, retrofit, public buildings.

\section{Introduction}

In most countries, the civil construction industry corresponds to a great share of the national GDP (gross domestic product). In Brazil, the productive chain of the sector is responsible for more than $9.2 \%$ of the GDP, corresponding to $40 \%$ of the total investments and generating more than 10 million jobs [1]. However, the civil construction industry is one of the economy sectors which has great impact on the natural environment [2]. This impact is due to the great consumption of materials, about $75 \%$ of the available natural resources, as it also occurs in the United States [3, 4]. In countries such as Japan, it is estimated that this consumption reaches $50 \%$ of raw material inputs [5].

The sector is responsible for $12 \%$ to $16 \%$ of the

Corresponding author: Mauricio Noya, master, Ph.D. candidate, research field: sustainability in civil engineering. E-mail: mauricionoya@hotmail.com. total water consumption, for $25 \%$ of the use of forest wood, for $30 \%$ to $40 \%$ of energy, and for $40 \%$ of extractive raw material. The sector is also responsible for the generation of $40 \%$ of residues of all human activities - during the execution of a construction, $15 \%$ of the materials become residues - among these, from $15 \%$ to $30 \%$ are deposited in landfills. The civil construction industry is also responsible for the production of $20 \%$ to $30 \%$ of GHEs (greenhouse gases), like carbon dioxide $\left(\mathrm{CO}_{2}\right)$, the main pollutant. In the world, $\mathrm{CO}_{2}$ emissions by the sector reach $3 \%$, mostly from the decarbonization of limestone during the production of cement [6, 7]. In Brazil, $\mathrm{CO}_{2}$ emissions reach $6 \%$ and the productive chain of the civil construction sector represents $8 \%$ of the total emissions of GHEs in the country [8]. A great share of the burning of fossil fuels must be added to these figures.

Another relevant fact in terms of environmental 
impact is due to the buildings and how they work. According to Watson [9], buildings are the greatest energy consumers of the planet. It is estimated that at a global level, the working of buildings is responsible for $25 \%$ of $\mathrm{CO}_{2}$ emissions - including not only direct emissions, such as the burning of fossil fuels for environmental conditioning, water heating and cooking, but also the indirect ones, such as the emissions associated to electricity purchased by others [10].

Therefore, the civil construction industry represents one of the most inefficient models of production and consumption there is ISAIA [6]. In Brazil, despite the growing concern in relation to environmental issues, civil construction is still at the beginning of what we could call the first stage of environmentally correct production. In this respect, we can point out legal documents such as Resolution n. 307/2002 by CONAMA (National Environment Council in Brazil) which sets guidelines, criteria and procedures for the management of residues in civil construction [11], and initiatives of sustainable construction like the two buildings which are the objects of study of this paper.

Agopyan and John [10] state that there is no sustainability without durability, in relation to the lifespan of the components, it would be essential for the classification of a construction as sustainable. Hence, the importance of choosing durable materials to be used in the constructions. When specified in the project phase, they will also define in quantitative terms the maintenance resources, as well as their impacts. The CIB's (International Council for Building) W82 Commission, upon giving concepts for sustainable construction, and also taking into consideration many other countries, has translated sustainable as durable [12]. This placement meets the concepts used in the refurbishing and maintenance of the building designed by Reidy, one of the objects of study of this article.

On the other hand, if all building projects demand changes in the pre-existing natural systems as well as the consumption of energy and inputs, which means that a completely "green" project is not possible, the ones oriented to sustainability represent an opportunity of improving environmental performance. Sustainability is a complex challenge, it comprehends not only how the resources are obtained, how they are used, but also, how to use them up to their full potential, considering non-wastefulness [13]. This is the case of the constructive project of the new MIS, which has also included techniques for reverse construction. According to the Technical Report 1 by Casa do Futuro, associated with the U.S. Green Building Council, the project has been developed in order to achieve better results in terms of environmental sustainability and the construction site must follow criteria and a set of concepts which will grant it the LEED (leadership in energy and environmental design) seal, a worldwide reference in sustainable certification in the last few years [9, 14].

The article draws a parallel between the refurbishing of an existing building, which uses sustainable techniques of environmental preservation, and the construction of a new building, based on environmental, economic and social criteria.

\section{The Life Cycle of Buildings}

In order to talk about preservation, demolition and new building, it is necessary to understand the concept of "Life Cycle of Buildings", which comprehends: the manufacturing of materials, their transportation to the construction site, the construction itself, the durability of the building, its maintenance and the demolition and recycling of the materials [15].

The acquisition of sustainability conditions in the three cases (preservation, demolition and building) depends on the assessment of the environmental impacts throughout these phases, such analysis is called LCA (life cycle assessment) of the building, a methodology of environmental management which evaluates, through qualitative and quantitative parameters, the potential impacts associated with a determined final product, so as to make it possible to 
have control of these impacts, their reduction or elimination [16]. The LCA, which has been used in civil construction since the nineties, has become an important tool for the evaluation of buildings in their two forms of application: The first one focused on the Whole Process of the Construction, and the second one focused on the Building Material and Component Combination [17].

According to Agopyan and John [10], the durability of the materials directly influences the length of time during which the building will render services, as well as the amount of resources to be used in its maintenance, defining environmental, social and economic impacts. The longer the lifespan of the building, the longer the preservation of the materials and the environment due to the reduction of the speed of flow of materials extracted from nature, which serve as raw materials for the constructions. On the other hand, if the longer the lifespan of the project, greater the risk of obsolescence, with techniques of sustainable recovery and the introduction of new concepts of use and building maintenance, it is possible to recover, use and manage the projects in a sustainable way [10].

These new concepts demonstrate that despite the importance of preservation during the life cycle, it is possible to opt for the new techniques and build with sustainability and social responsibility through reverse construction, which becomes a sustainable demolition, within the reuse of all material which otherwise would be dumped in a landfill. The recycling of residues and their utilization as raw materials is a measure of fundamental importance for the preservation of natural resources; not only does it collaborate to the reduction of the consumption of energy, but also guarantees the preservation of the environment [18].

\section{Case Studies}

The study refers to two individual constructions, an initiative of the Government of the State of Rio de Janeiro, which aim at only one goal: the sustainability in civil construction. Respecting the characteristics of the building, the first one (Fig. 1) proposed changes in the pre-existing natural systems and also in the consumption of energy and inputs. The retrofit project has presented preservation material sustainable techniques, as well as the substitution of equipment and systems so as to acquire better environmental development. The second case, the construction of the new MIS, Fig. 2 was totally projected based on sustainability principles. For that matter, it was initiated undergoing the process of reverse construction, having selective demolition, as well as the recycling of the withdrawn material. The project of the new museum anticipates the reduction of the energy charge used in the heating, lighting and cooling systems, with emphasis on indoor air quality.

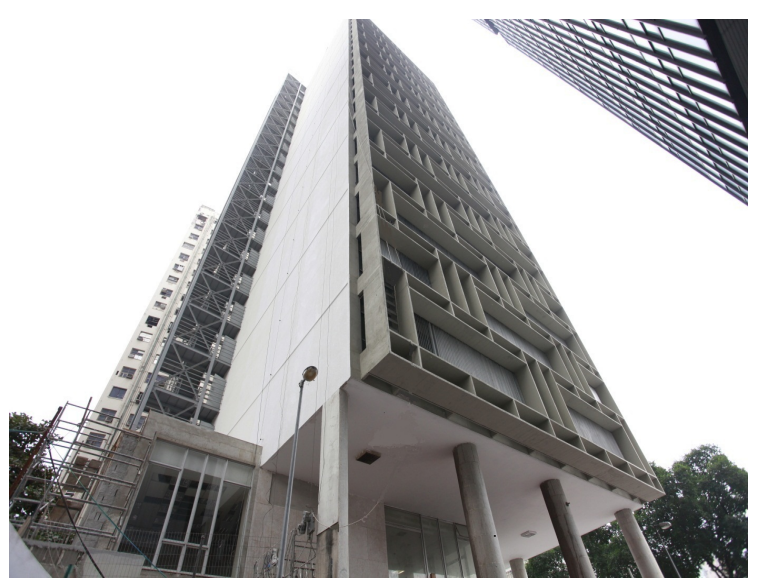

Fig. 1 Retrofit project of the modernistic architecture [19].

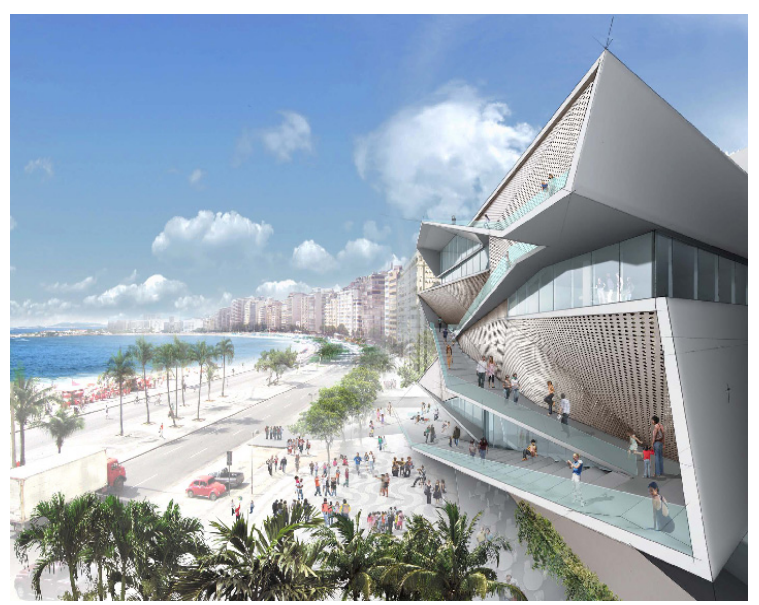

Fig. 2 The construction of the new MIS [21]. 


\subsection{The Old IPEG Building}

The old IPEG (Instituto de Previdência do Estado da Guanabara) building is located on the corner of Presidente Vargas Avenue and Andradas Street, downtown Rio de Janeiro. The 22-story building designed by Affonso Eduardo Reidy, became a landmark in Rio de Janeiro architecture in the fifties because it was the first building in the city to use a metallic structure (Figs. 3 and 4) [20]. The modernist building has its frontage facing south and west. As the south face is almost the whole year in the shade, it is totally made of glass while the west face, which is subject to intense sun rays throughout the day, has a brises soleil system which protects the building against solar radiation (Fig. 5). This kind of forecast in the project demonstrates the architect's concern, at that very time, about issues such as environmental comfort and cooling efficiency, which can be translated as energy efficiency, since the thermal conditioning is one of the greatest villains, responsible for the electric power consumption in the operational phase of the building, as well as in electric power consumption in the construction phase [22].

The construction that hosts the State Department of Taxation and Finance has its own team of architects. They have remodeled all the floors (Fig. 6) according to new needs, this remodelling was performed by EMOP - a Public Construction Company. In accordance with the new desires of the administration and corresponding to the need of economic operational results and maintainability oriented to sustainability, the retrofit was really important for the city, especially because it aimed at preserving an awarded architecture. Because of this challenge, the insertion process of new techniques and concepts environment oriented was initiated.

The buildings are responsible for $42 \%$ of the total consumption of electric power generated in Brazil. Recent studies have shown that residential buildings consume $23 \%$ of energy, commercial ones $11 \%$ and public ones $8 \%$. In office buildings, air-conditioning

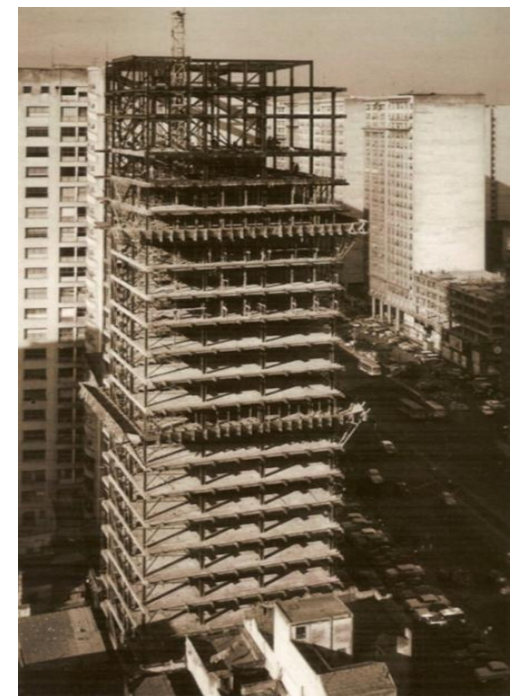

Fig. 3 The construction in 1950, west facade [20].

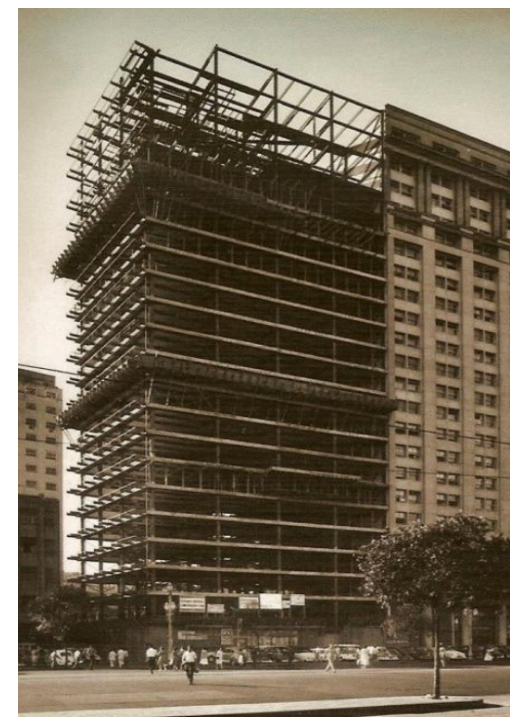

Fig. 4 The construction in 1950 south façade [20].

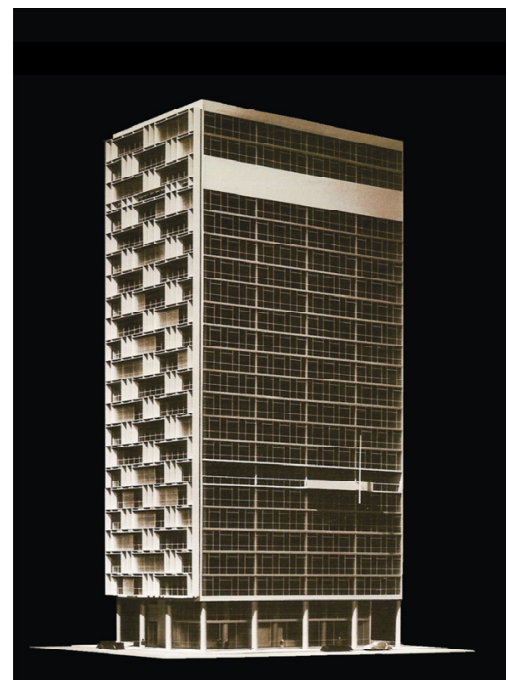

Fig. 5 Model of the building, west and south facades [20]. 
consumes $48 \%$ of energy [23]. For that reason, the cooling system Fig. 7 was completely replaced. The old system used to have a cooling tower, which makes the cooling obsolete, causes a high consumption of electric power and a great waste of water (through evaporation and natural system loss), besides the high cost of water chemical treatment required by this kind of equipment. The new cooling system, Fig. 8 has chillers with internal tanks made of serpentines where the water circulates producing the cooling. These internal tanks are not only responsible for water economy, but also for stopping its evaporation, providing greater energy efficiency and less loss, thus making the system more economical, efficient and sustainable.
Regarding the rational water use, it stands out the replacement of all restroom units. In the original project, in Fig. 9, the adopted system used pressure valves, which are responsible for high consumption and water waste. In the refurbishing, a Dual Flush system was used (Fig. 10), it allows the liberation of three liters of water for liquids and six for solids. Data about the real economy of this system vary considerably, however, using it, we can reach an economy of $6.480 \mathrm{~L}$ of water per person annually. That allows us to classify it as being sustainable [25]. The original faucets, Figs. 11 and 13 were also replaced by faucets with timer system Figs. 12 and 14, which limits the water flow and saves up to $40 \%$.

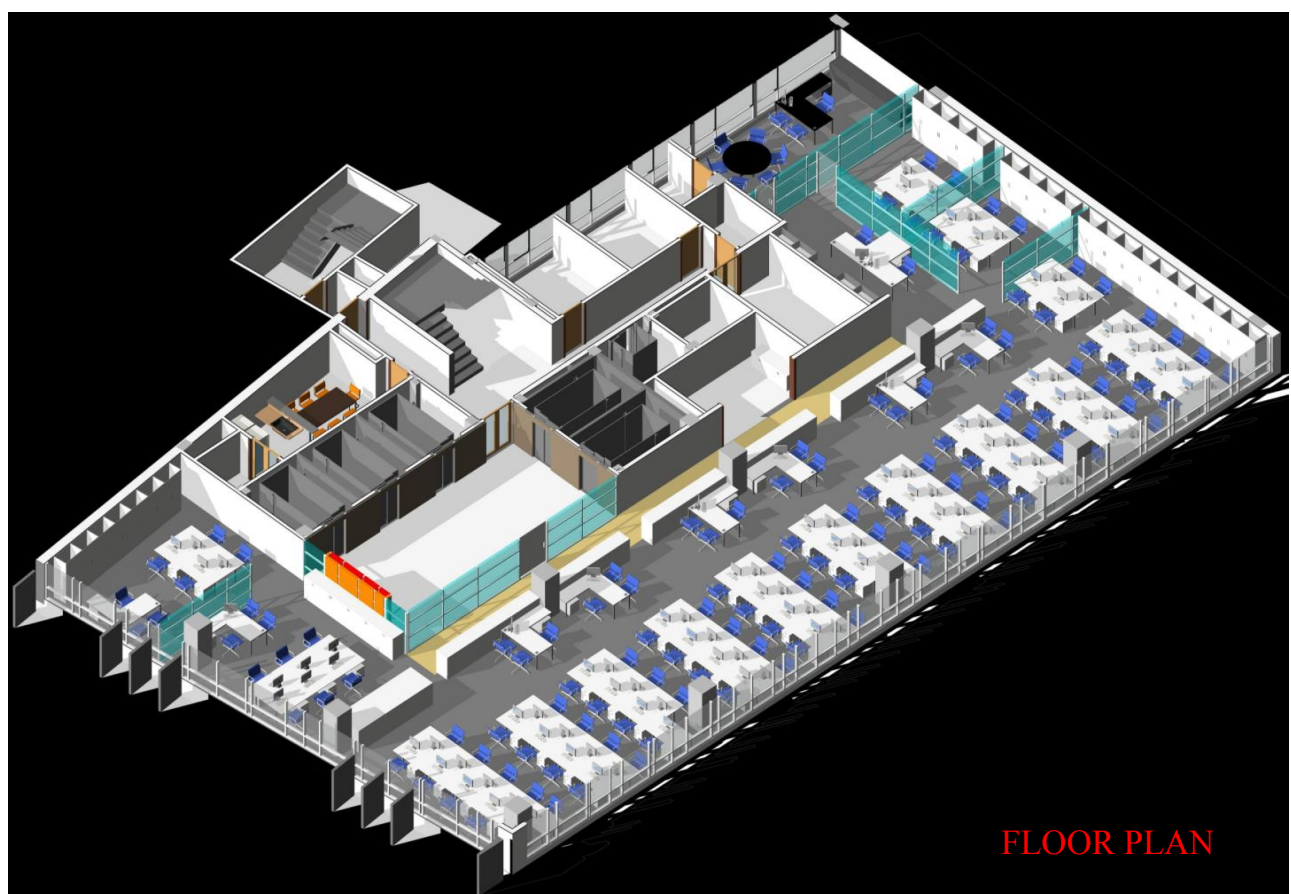

Fig. 6 New layout of the floors.

Source: State department of taxation and finance architecture (2011).

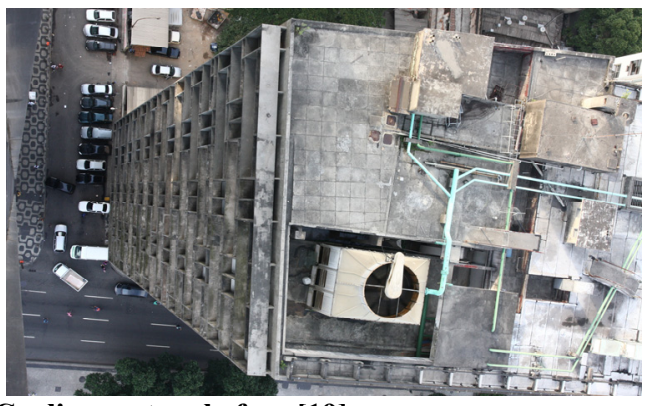

Fig. 7 Cooling system before [19].

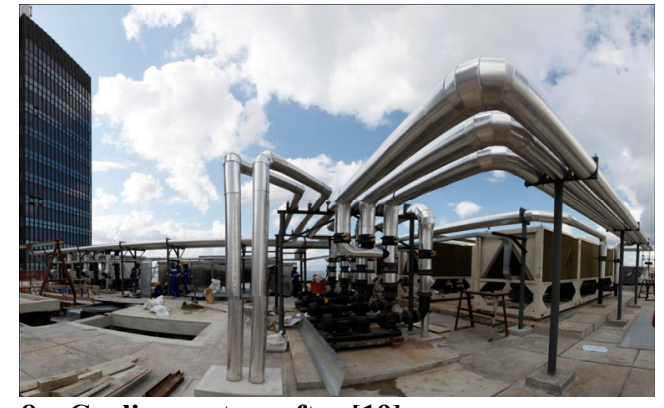

Fig. 8 Cooling system after [19]. 


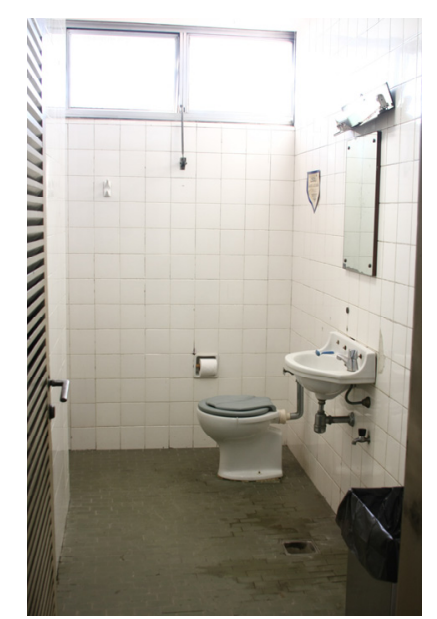

Fig. 9 Bathrooms before: pressure valve system [19].

Another relevant aspect was the implementation of the selective waste collection. With $100 \%$ of the materials of consumption properly dumped, the recyclable waste receives selective treatment. Selective trash cans were also placed in all areas of the building, including the offices. The trash, which is separated in specific bags, is collected by registered and authorized non-governmental organizations for the purpose of recycling. This measure is according to Decree n. 5.940/2006, which issues the separation of recyclable residues discarded by Public Administration Entities, as well as their destination to recycling [26].

Disposable cups were replaced by customized mugs. Besides coming from fossil materials, they have cancer-stimulating effects in their formula, with an amount of styrene above the one recommended by the

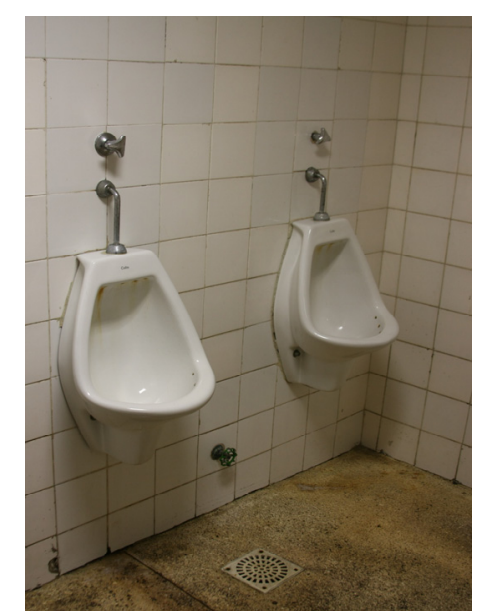

Fig. 11 Bethrooms before: urinals with original faucets [19].

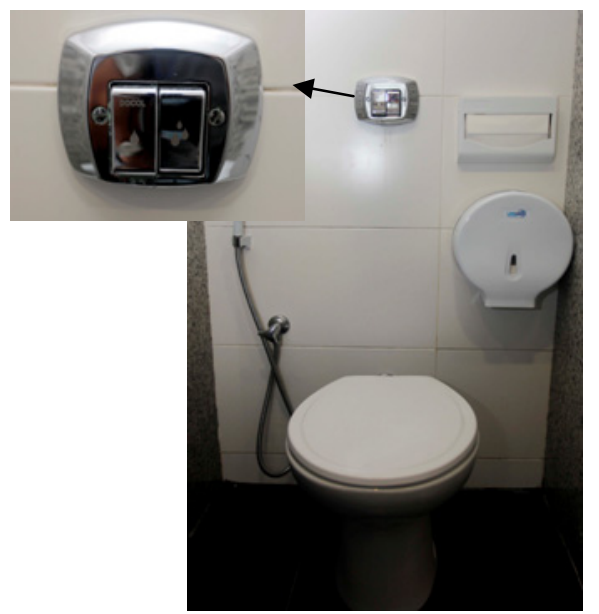

Fig. 10 Bathrooms after: dual flush system [24].

Ministry of Health (20 ng/mL-L) [27].

The project prioritized suppliers that perform their activities in a sustainable way, observing the life cycle of their products. The supplier of the raised flooring installed in all floors uses raw-material from the plastic waste processor (Fig. 15).

The conventional solutions use aluminum plates which weigh about $45 \mathrm{~kg} / \mathrm{m}^{2}$. The $12 \mathrm{~kg}$ solution used in the building is formed by recycled polypropylene plates inlet on paving slabs. The covering of this floor was made of carpet tiles which reduces waste generation when compared to roll carpet: something like $3.9 \%$ against $13.1 \%$ of the traditional roll carpets. The strands of the carpet tiles are made of recyclable materials, which eliminate the use of virgin raw-materials, while the office furniture was made of recycled material. The supplying company uses $100 \%$

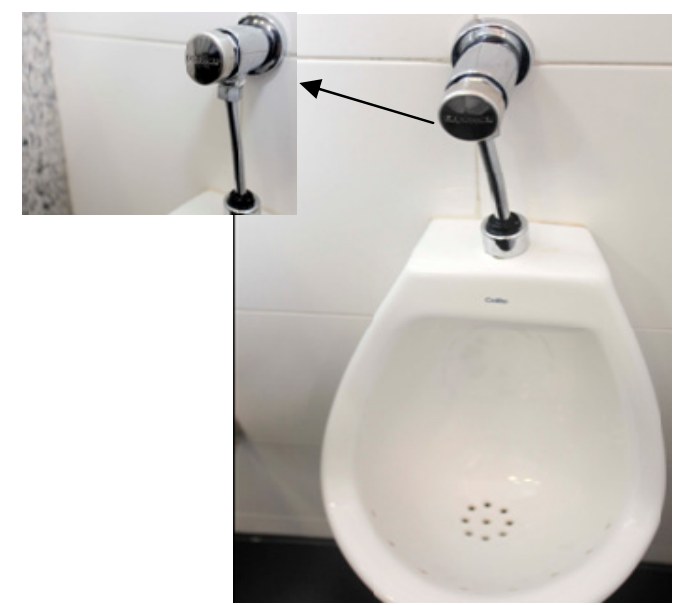

Fig. 12 Bathrooms after: urinals with timer system [24]. 


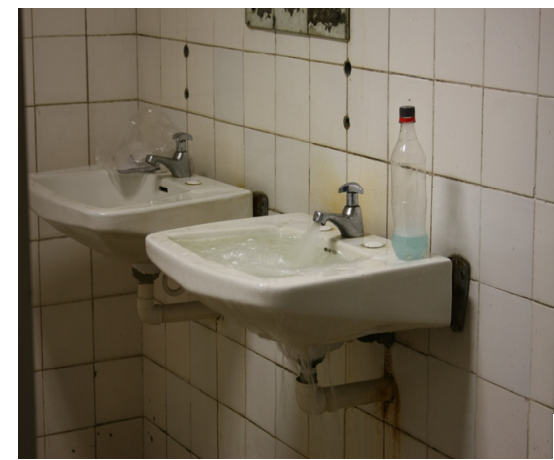

Fig. 13 Bethrooms before: original faucets [19].

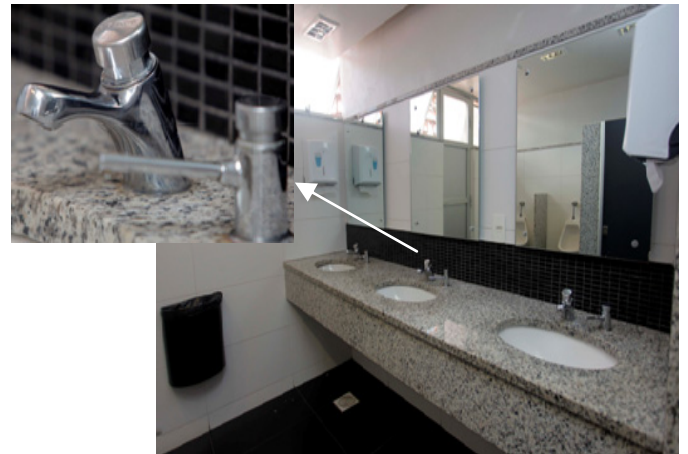

Fig. 14 Bethrooms after: timer system faucets [24].

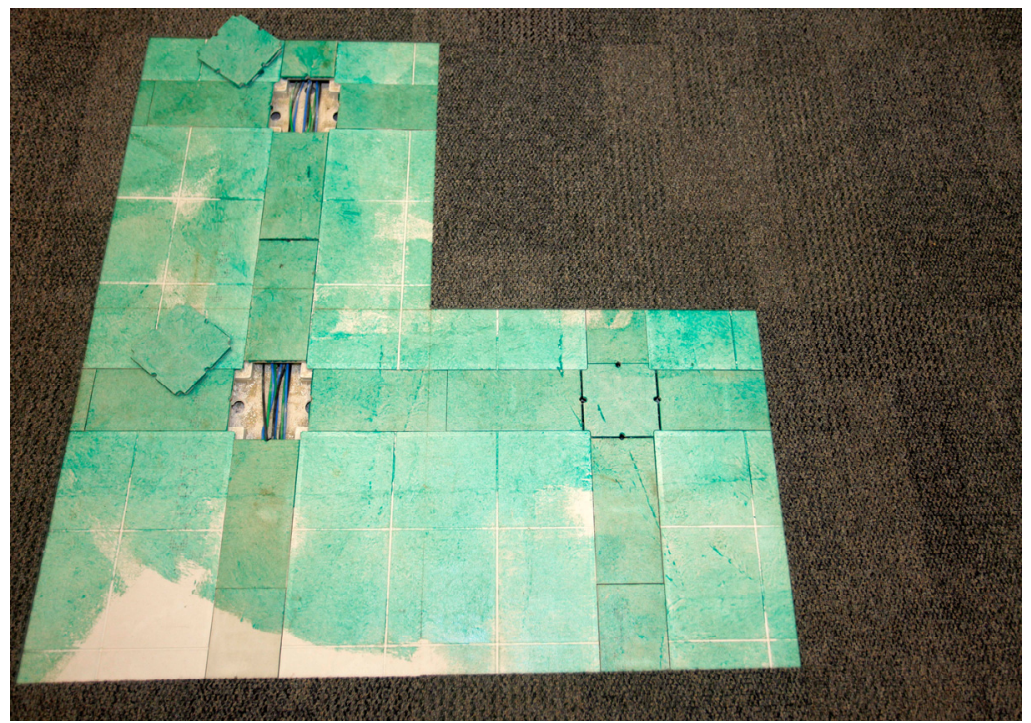

Fig. 15 Raised flooring and carpet tiles used installed in all floors [24].

reforested wooden planks, certified by FSC (Forest Stewardship Council). Besides, it also has a program of waste management, machinery which reduces the consumption of energy and the emission of pollutant gases, it also uses procedures in order to make good use of daylight in the factory, it has selective waste collection among other ecological initiatives that are really important for the environment preservation. Fig. 16 shows the original furniture replaced by a new conception (Fig. 17).

Finally, the project has developed an alternative transportation program, which provides parking bicycle racks and creates special parking spots for vehicles used for carpooling.

The refurbishing attempted at inserting new techniques in the operational and maintenance system in a consistent measure because they positively interfere in the habits and behaviors, meaning an improvement in salubrity conditions for the personnel, the maximization of operational efficiency and minimization of environmental impacts.

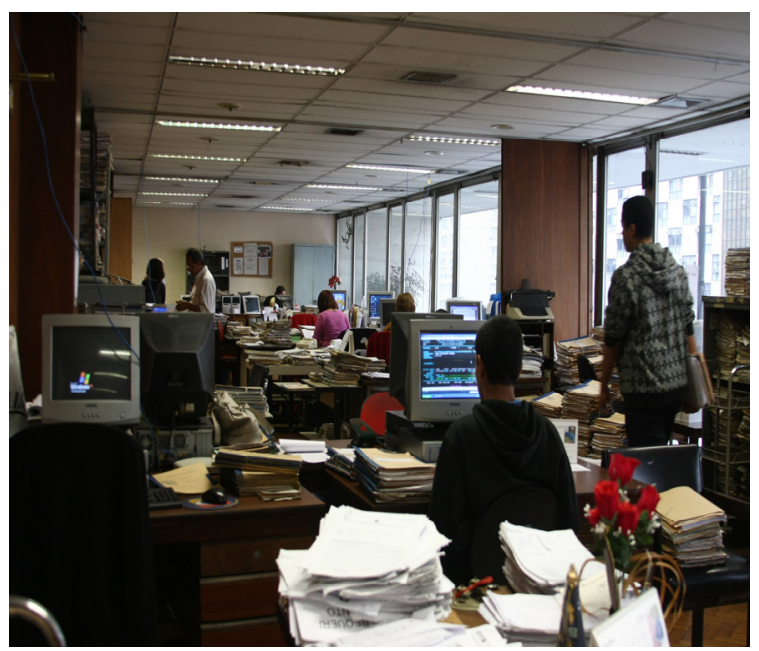

Fig. 16 Office furniture before [19]. 


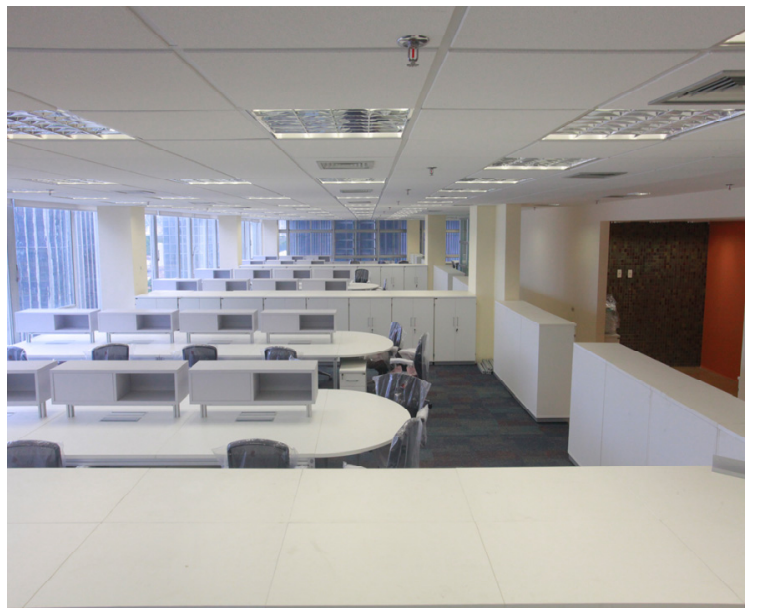

Fig. 17 Office furniture after [19].

\subsection{MIS (Museum of Image and Sound)}

The construction of the new museum of image and sound is a partnership between Rio de Janeiro State Government and Roberto Marinho Foundation. It is the base of the sustainable revitalizing process of Copacabana beach and we hope it will become a reference in sustainability for the whole Brazilian Patrimony and Culture field [9]. Diller Scofidio + Renfro office was the winner of the contest concerning the choice of the new museum architectonic project, which, composed of seven floors located on Atlântica Avenue, will take the space once occupied by "Boate Help", which was completely demolished to give place to this new construction. The project will be registered at USGBC (United States Green Building Council), a non-governmental organization created in 2007, and it may be the first institution of the kind to receive the LEED (leadership in energy and environmental design) certificate [9]. Fig. 18 illustrates the eletronic model of the museum frontage.

Differently from the first case study, in which obsolescence was overcome by specific strategies of the project, such as the insertion of new techniques and concepts based on sustainability, the sustainability of MIS started to be thought since the project design and in a integrated form. In order to be granted with the LEED seal, an American design office specialized in environmental consultancy was hired, as well as another consultancy company from Rio de Janeiro [9].

The work, based on the sustainability of the construction, has already started at the demolition day of the old Boate Help building (Fig. 19). The sustainable

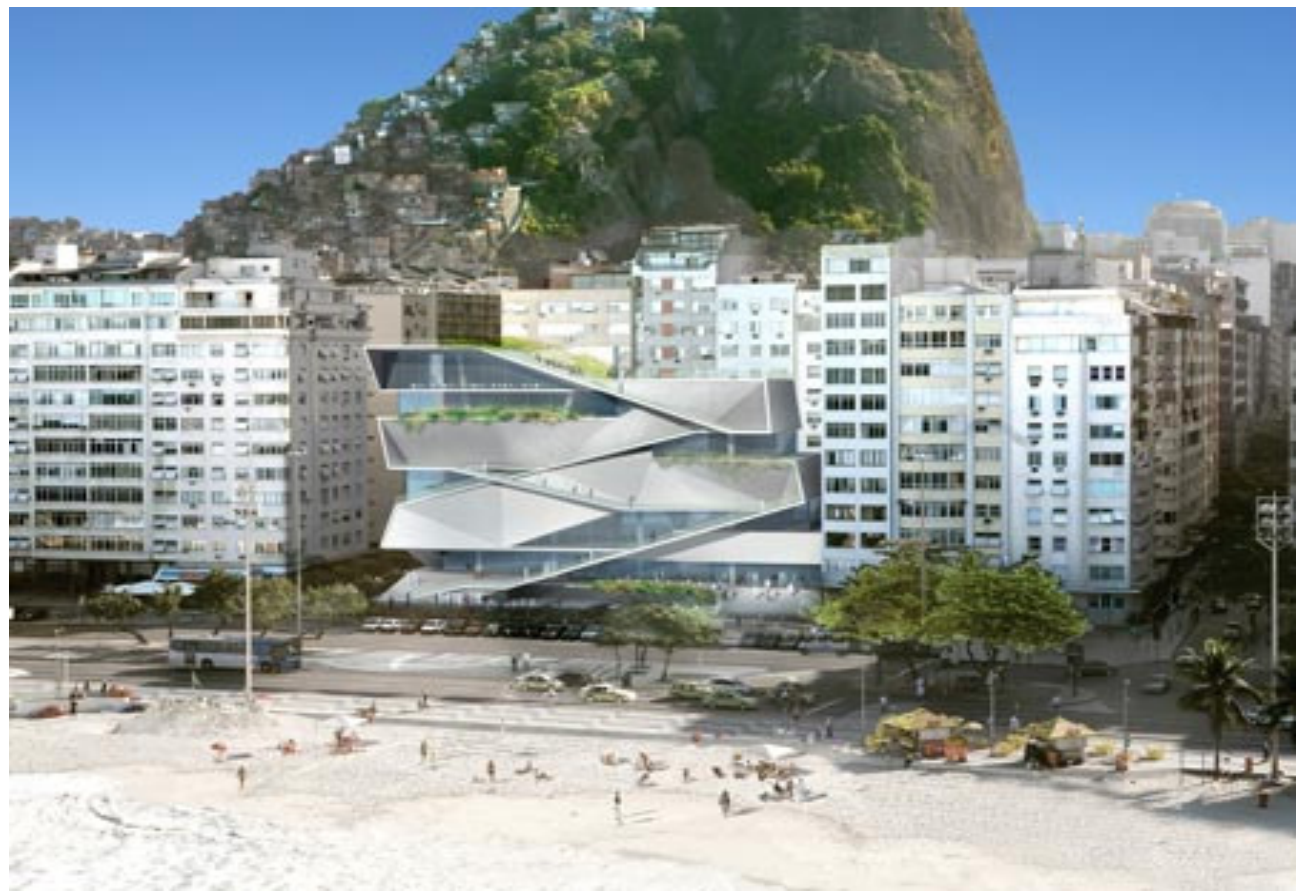

Fig. 18 MIS electronic model frontage [21]. 


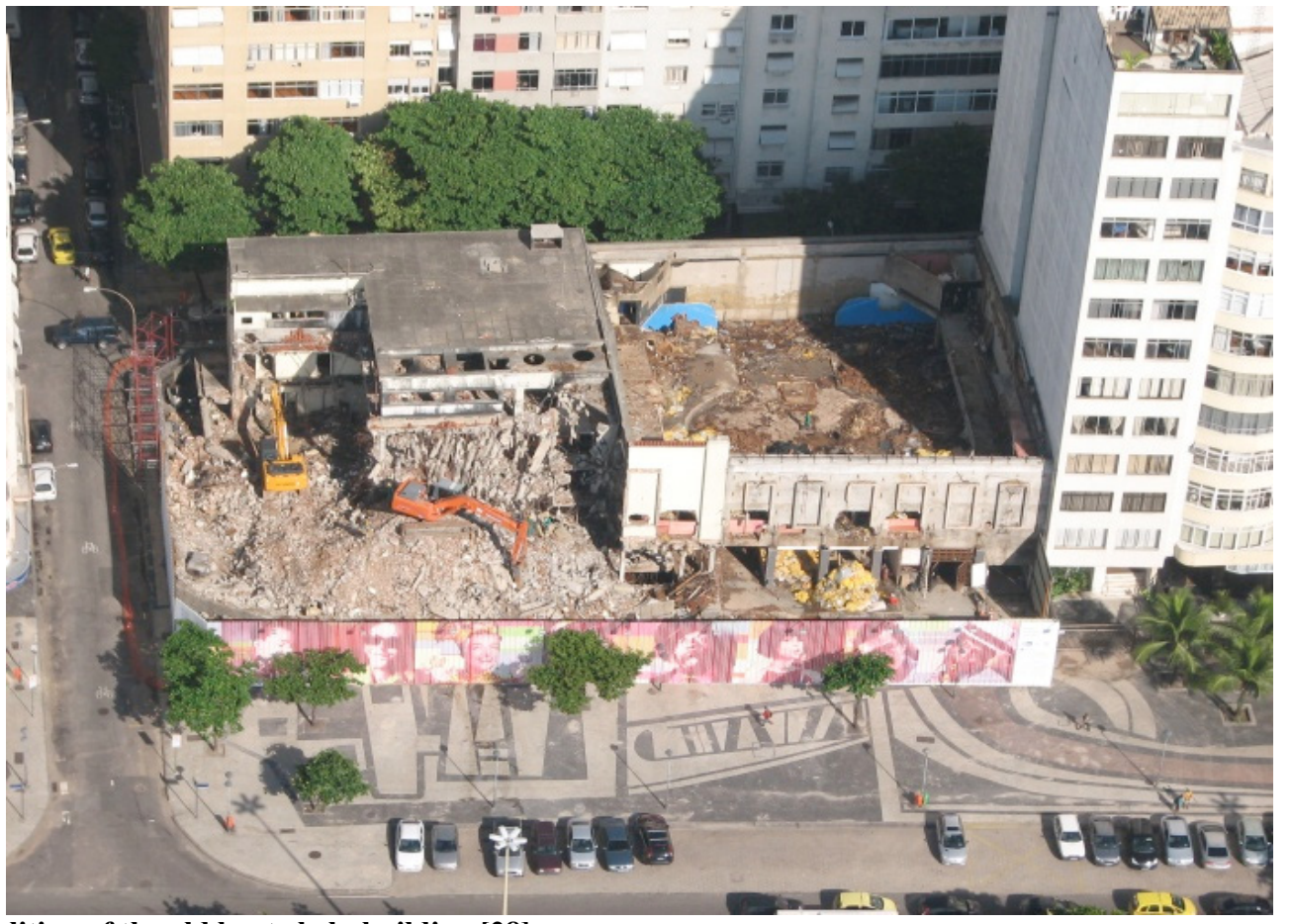

Fig. 19 Demolition of the old boate help building [28].

demolition (or reverse construction) tried to reduce problems such as dust, noise and dirt [9]. This different demolishing process certainly provided more safety to the surrounding neighborhood. The principle of reverse construction depends on the selection of the "in loco" material. According to CONAMA Resolution n. 307, all the material must be carefully separated at the site [11]. Therefore, materials such as wood, shingles, bricks, glass, aluminum, metals, among other things that otherwise would become debris, are carefully separated at the site. Despite taking more time than the conventional discard, the apparent initial loss of this process is worth it, since the additional costs are avoided. The selective practice of waste segregation allows better management at the site, besides the commercialization easiness [10].

It was exactly what happened at the demolition phase of the old building at the MIS construction site: There was separation and selection of materials that might be reused or recycled, either in the site or elsewhere. Whatever would serve as raw material for the making of new materials have remained at the construction site, for example, the concrete plaques which were ground for re-utilization in paving material. While the recyclable or reusable material was donated to NGOs and cooperatives in order to be turned into other diverse products. This way significantly contributed to the reduction of transportation costs and emission of greenhouse gases, besides helping those who make a living of this kind of commerce [9].

This procedure is very relevant, considering that the amount of waste generated in civil construction due to demolitions is the same or at least superior to the amount of urban garbage, approximately 400 $\mathrm{kg} /$ inhabitants/year [7]. Obtaining new materials from recyclable ones means reducing the rate of discarding and consequently, the exploitation of natural resources for the transformation of raw material for the industry, besides creating new business opportunities and jobs for the population. Sustainable demolition creates direct and indirect beneficiaries, environment, society, workers involved (who take advantage of these new techniques and acquire new sustainable habits), and people who develop similar activities, like craftsmen or garbage collectors. According to the United States 


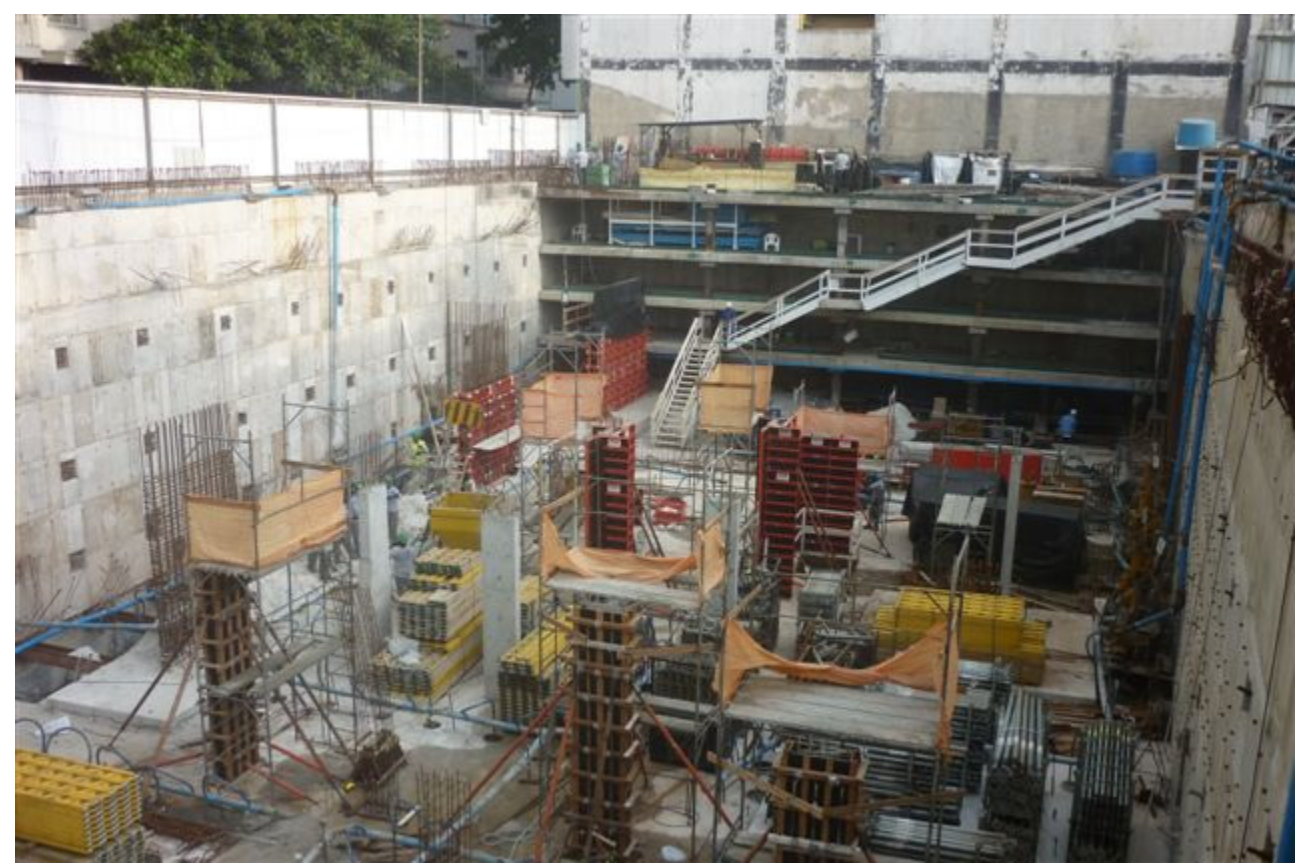

Fig. 20 Evolution of the construction site [29].

Green Building Council, an outstanding environmental undertaking is characterized for minimizing or even eliminating its negative impact on environment and its users. The council evaluates the environmental performance of buildings in five concepts: sustainable planning of the constructed area, water economy and efficiency in its use, power efficiency and use of renewable energy, conservation of materials and sources of resources, and quality of indoor environment [30]. The project of the new MIS aims at better results in terms of environmental sustainability and the construction site must follow the same criteria which will allow the achievement of the LEED certification. In order to reduce the negative impacts in the environment, the building strictly follows all the regulating determinations for achieving sustainable development in civil construction, in a pioneering initiative in the city. Fig. 20 shows the evolution of the construction.

Forecasting the reduction of energy consumption, the consultancies made a simulation that enabled them to elaborate a "thermal picture" of the building, taking into consideration solar radiation, relative humidity, wind frequency, the localization (since it is across from the sea, it makes the use of natural ventilation difficult and it may damage some electronic equipment used in the exhibitions of the museum); and the climate of the city throughout the seasons of the year [9]. According to Lodi [9], former coordinator of projects in the Roberto Marinho Foundation and current project supervisor at IPHAN-Rio (National Historic and Artistic Heritage Institute), criteria optimization of natural lighting, use of ideal glasses, air conditioning systems that meet the environmental comfort of the workers and users, solar power for water heating and the transformation of the air-conditioning water into energy, as well as a green roof, are under study.

The project establishes new sustainability techniques and promotes good practices that can be applied to other cultural assets of the city, since it is considered a pilot project by Rio de Janeiro State Government, not only with the intention of giving sustainability to the buildings but also with the purpose of educating Brazilian society.

\section{Conclusions}

The objective of this article was to approach the 
sustainability in civil construction theme by reporting clean techniques of pre-production, production and utilization of resources used in both individual cases. In the retrofit work of the modernist style building, designed by the architect Affonso Eduardo Reidy, it was demonstrated that it is possible to preserve old and important buildings in a sustainable way taking into consideration not only new concepts, techniques and sustainable habits, but also efficient and more economic equipments in their work, optimizing resources utilization, reducing the $\mathrm{CO}^{2}$ emissions and providing environmental comfort for their users. These concepts can also be applied to the construction of new undertakings, as the case of the MIS. If the construction is based on sustainability fundamentals and on the eventual application of their principles in the pre-construction or demolition phase, represent the concretization of that which is an important perspective for the civil construction and architecture fields nowadays. The application of new project and constructive techniques oriented to the preservation of the environment make the involved professionals have more responsibility, not only because of the cost of the undertaking, but also because of the impact that the new buildings cause to the environment. Studies demonstrate that it is possible to adopt new sustainability techniques, from the making of the products to the construction site, with the reuse of the materials, through the selective demolition of inputs. Despite not reaching the total reuse in some cases, the study shows that the waste which is not used may be discarded in a correct way so as to do no harm to the environment.

It is worth mentioning that, in spite of having clear objectives to be accomplished within the implementation of a cleaner production, there are still some obstacles to be overcome, particularly when it comes to cultural aspects, lack of information and also the adherence to past habits and old behaviors. Balancing social, economical and environmental development is still an enormous challenge. Hence, there is huge urge for commitment among professionals and the society as a whole towards sustainability in order to assure society a better future with superior quality.

\section{References}

[1] CBIC (Brazilian Chamber for the Construction Industry), Civil Construction: Analyses and Perspectives, 2010, http://www.cbcs.org.br/ (accessed Oct. 6, 2013). (in Portuguese)

[2] G.C. Grigoletti, M.A. Sattler, Environmental strategies for Brazilian red ceramic industry in Rio Grande do Sul State, Built Environment 3 (3) (2003) 19-32. (in Portuguese)

[3] V.M. John, S.C. Ângulo, S.E. Zordan, Sustainable development and waste recycling in civil construction, in: Proceedings of 4th Workshop on Sustainable Development and Recycling in Construction, São Paulo, 2001. (in Portuguese)

[4] G. Matos, L. Wagner, Consumption of materials in United States 1900-1995, Annual Review of Environment and Resources 13 (1998) 107-122.

[5] Y. Kasai, Barriers to the reuse of construction by-products and the use of recycled aggregate in concrete in Japan, in: R.K. Dhir, N.A. Henderson, M.C. Limbachiya (Eds.), Use of Recycled Aggregate, Tomas Telford, 1998, pp. 433-444.

[6] G.C. Isaia, Civil Construction Materials and Science Principals and Materials, Vol. 2, Ibracon (Brazilian Institute of Concrete), São Paulo, 2007. (in Portuguese)

[7] V.M. John, Waste recycling in construction: A contribution towards research methodology and development, Habilitation Thesis, Polytechnic School of the University of São Paulo, São Paulo, 2000. (in Portuguese)

[8] McKinsey and Company, Ways towards Low Carbon Emission Economy in Brazil, São Paulo, 2009. (in Portuguese)

[9] C. Lodi, Social, Economic and environmental sustainability in the new museums of Rio de Janeiro: Museum of tomorrow, MAR-Museum of art of Rio de Janeiro and the new museum of image and sound, in: Proceedings of 2th International Workshop on Museography and Museum Architecture: Identity and Communication, Rio de Janeiro, 2010. (in Portuguese)

[10] V. Agopyan, V.M. John, Sustainability Challenges in Civil Construction, Edgard Blucher, São Paulo, 2011. (in Portuguese)

[11] Ministry of Environment, 2002, CONAMA (National Environmental Council of Brazil) Resolution Number 
307, July 5, 2002, Federal Official Gazette of Brazil 136, Brasil, July 17, 2002, pp. 95-96. (in Portuguese)

[12] L. Bordeau, Agenda 21 on Sustainable Construction, Rotterdam, CIB, 1999, p. 120. (in Portuguese)

[13] Doerr Architecture, Definition of Sustainability and the Impacts of Building, Colorado, EUA, doer.org $/ \mathrm{html} /$ GreenChecklistResidential.doc (accessed Jan. 1, 2012).

[14] Museum of Image and Sound, Technical report 01: Worksite and Assembly Monitoring, Rio de Janeiro, June 20, 2011. (in Portuguese)

[15] S.F. Tavares, R. Lamberts, Energy consumption for construction, operation and maintenance of residential buildings in Brazil, in: Proceedings of Brazilian Meeting on Built Environment Comfort, Brazil, 2005. (in Portuguese)

[16] J.R.B. Chehebe, Product Life Cycle Assessment: ISSO 14000 Management Tool, Qualitymark, Rio de Janeiro, 2002. (in Portuguese)

[17] O. Ortiz, F. Castells, G. Sonnemann, Sustainability in the construction industry: A review of recent developments based on LCA, Construction and Building Materials 23 (2009) 28-39. (in Portuguese)

[18] V.M. John, S.E. Zordan, Research and development methodology for recycling residues as building materials, Waste Management Series 21 (3) (2001) 213-219.

[19] M. Coelho, Photographic Collection of the Latter IPEG Building, State Department of Taxation and Finance, Rio de Janeiro, 2011. (in Portuguese)

[20] N.G. Bonduki, Affonso Eduardo Reidy, Brazilian Architecs, Editora Blau, Lisboa, 2000. (in Portuguese)

[21] Diller Scofidio + Renfro, 2011, MIS, http://www.dsrny.com/ (accessed Jan. 1, 2012).

[22] J.W.M. Kaehler, M.B. Garcia, L.A. Pereira, Civil construction industry, in: Proceedings of International Workshop on Energy Efficiency, Campinas, 2006. (in Portuguese)

[23] C. Escudero, News: Energy Efficiency, Construction \& Bussiness Magazine, São Paulo, Jan. 13, 2012. (in Portuguese)

[24] D. Normando, Photographic Collection of Rio de Janeiro State Department of Taxation and Finance, Rio de Janeiro, 2013. (in Portuguese)

[25] C.G.S. Dusse, Company Runs a Campaign for Saving Water in Restrooms, Brazilian Newspaper "O Debate"-Science and Environment, July 3, 2008, www.odebate.com.br (accessed Jan. 1, 2010). (in Portuguese)

[26] Decreto $n^{\circ}$ 5.940, It Defies That All Disposed Recyclable Waste Must Be Direct and Indirectly Managed by the Federal Government Not Only at the Generating Sources, but also at Associations and Cooperatives of Recyclable Materials Collectors, Brasil, Oct. 25, 2006. (in Portuguese)

[27] P.A.P. Pereira, R.F.S. Oliveira, J.B. Andrade, Determination of styrene content in polystyrene cups by purge-and-trap followed by HRGC-FID, American Laboratory News 36 (15) (2004) 16-18.

[28] Rio de Janeiro State Department of Taxation and Finance, Architecture Department, Rio de Janeiro, 2011. (in Portuguese)

[29] Photographic Collection, Rio de Janeiro State Department of Culture 2010/2012, Rio de Janeiro, 2012. (in Portuguese)

[30] An Introduction to the US Building Council and the LEED Green Building Rating System, Washington DC, USGBC (United States Green Building Council), Mar. 2002. 